A review of Public private partnerships around girls' education in developing countries: flicking gender equality on and off

Elaine Unterhalter, UCL Institute of Education

\begin{abstract}
The article reviews the literature on Public Private Partnerships (PPPs) and policy on girls' schooling in developing countries. It considers the ways in which aims around gender equality and women's rights are positioned in policy texts concerned with girls' education PPPs. The argument made is that these documents exemplify an oscillation, using a multipolar register, between pragmatic initiatives that recognise existing sites of power, and attempts to develop a political project that dissolves differences between public and private constituencies, who share an interest in getting girls into school. The potential and limits of this approach to support integrated policy around rights and equalities is considered using the case of DFID's Girls' Education Challenge. An analytical framework is sketched that maps a political and epistemological process termed dispersal, which is used to consider some ways to investigate the effects of PPPs as a mechanism to address intersecting inequalities.
\end{abstract}

This article analyses literature on public private partnerships (PPPs) associated with girls' schooling in developing countries, drawing out some of the ways these arrangements suture together tendencies that lean towards and away from concerns with gender equality and women's rights. PPPs seem to exemplify policies and practices around gender that span sometimes incommensurable goals associated with human rights, equalities, security, military strategy, transparent governance, sustainable development, and partnerships with corporations. In this discussion some consider improving girls' access to school a uniquely effective step to secure development (Kristoff and WuDunn, 2009; Warner, Malhotra, \& McGonagle, 2012). Others critique aspects of the confidence of these claims (Duflo, 2012; Switzer, 2014; Chant, 2016).But less remarked in this debate is an alignment in policy advocacy for girls' schooling between the state, the private (for profit) sector, and equality oriented NGOs, who have often collaborated through PPPs. This article examines some experiences with PPPs in girls' education focusing on the DFID funded Girls' Education Challenge (GEC), initiated in 2011. In GEC, PPPs comprise a significant component of the work 
of management, delivery and evaluation. While it is too early to document some of the outcomes of this PPP, the discussion considers whether or not the partnership framework sets up a space for in depth engagements with gender equality and women's rights.

The first part of the discussion reviews some definitions of PPPs in education, and some literature on PPPs and girls' education. The second part outlines the work of GEC between 2011 and 2016 drawing on policy and evaluation documents. The final part uses the term multipolarity as a heuristic to help capture processes outlined in GEC, associated with PPP formation, where gender issues in education operate both as a social justice project and to sanction or sanitise relations of commodification or continued inequalities. In concluding, I outline some possibilities of using the heuristic of multipolarity to understand what is signified and delivered through PPPs.

\section{Definitions and contexts}

Since the 1990s PPPs have been advocated to enhance the provision of education in the global north and south.( LaRoque, 2008; Robertson, Mundy and Verger; 2012; Pestoff, , Brandsen,., \& Verschueren 2013; Draxler ,2015) A range of different kinds of partnership are entailed, including public sector contracts with the private sector to deliver core components of the education system or support services, publicly subsidised education in private schools through vouchers or other financial arrangements, philanthropy in a range of guises spanning policy advocacy and building of public schools, and governance mechanisms which include collaborations between government, profit and non-profit third sector organisations.

There is no single way that PPPs link with work on gender equality in education, partly because this concept itself is so fluid (Unterhalter, 2016). PPPs have been lauded as offering girls opportunities for schooling, denied by standard public provision in developing countries (Patrinos., Osorio, \& Guáqueta, 2009), cautiously considered because of potential to support advocacy around equalities and enhanced service in Africa and South Asia (Rose, 2010 ), and criticised as deepening gender inequalities, by diminishing the state's capacity to support gender equality frameworks in India ( Srivastava, 2010). Charges against PPPs in India and Pakistan include the employment of low paid women teachers, and ambiguous signals on gender equality in secondary education (Brans, 2013). In their evaluation of DFID's work on 
education, gender equality and women's empowerment in a range of developing countries, Rose and Subrahmanian (2005) argue that private providers, sometimes working in partnership with the state encompass initiatives for better quality services, reserved for those who can pay, and projects which offer 'last chance' opportunities for the poorest where insufficient school places are available. Public policy on gender equality and girls' education can thus be supported or diluted by PPPs. Harma (2015) details many forms private schooling may take, and the multiplicity of relationships with the government which may be termed PPP. A minimal registration of private schools with a government department for a nominal fee is generally a form of regulation, but PPPs entail, for example the provision of teachers in private schools paid from public funds, and substantial allocations of public money to running privately owned schools.

PPPs have different gender effects. An enlargement of opportunities for some groups has been noted in some settings in Pakistan, notably groups of girls who are given more schooling opportunities and women who have more employment possibilities (Andrabi et al, 2002; Fennell, 2014). But we do not have enough country specific studies to know if these effects are found in other contexts and are clearly causally linked with PPPs. Studies of PPPs, girls' schooling and gender equality in India note the low pay rates of the women teachers, and the minimal education provision that continues in state schools, without PPPs, limiting possibilities to secure wider rights (Manjrekar, 2013; Kelly,Krishna and Bhabha, 2016). Comparative study indicates sustained public provision of education in China has done more to support the achievement of gender parity in schooling than the state, PPP and private mix in India ( Smith \& Joshi, 2016). Thus the record of PPPs in contributing to enhancing girls' and women's rights and expanding gender and other equalities seems context dependent.

Although context appears an important strand of whether or not PPPs may deliver expanding gender equalities and enhancing women's rights, careful consideration of contextualisation appears not to have been a major theme in advocacy for PPPs. Draxler's review of the history of PPPs in education $(2016,443-4)$ notes the enthusiasm for this policy has partly been animated by multilateral bodies' wish to generate funds from corporations to help fill the funding gap to realise goals associated with Education for All (EFA) and the Millennium Development Goals (MDGs). Given that gender parity concerns are a significant thread in 
these international policy frameworks, with gender equality more muted (Unterhalter, 2007), this might explain some of the oscillations around PPPs and gender, and the ways in which the complexities of local gender inequalities and struggles around rights appear and disappear in the advocacy for PPPs.

Whether or not there is substantial concern with gender in PPPs or token gestures rests partly on the national and international dynamics of work on gender equality in education. Enthusiasm of international policy makers, who have promoted PPPs, has partly been driven by the inability of many governments in poor countries to deliver on EFA and MDG commitments because of a low tax base to meet historic under provision, inadequate aid, high levels of corruption, or a combination of all three ( Robertson, Mundy, and Verger, 2012.) Thus the process of arguing for PPPs appears to have been driven by governance and rollout issues rather than agendas around rights or equalities, and how to root and sustain these in local demands.

The discussion about PPPs in education is highly polarised with advocates lauding the substantial benefits derived from enhanced expertise, shared risk, and new resources, with somewhat limited reflection on context or gender relations (Patrinos., Osorio, \& Guáqueta, 2009). Critics, also write with little attention to gender dynamics in particular contexts, but note the erosion of public services, undermining of professional development for teachers, the deepening of inequalities, and the failures to go beyond easy wins, and 'low hanging fruit' in terms of expanding schooling (Robertson, Mundy, and Verger, 2012; Menashy, 2014; Menashy, 2016). Draxler's $(2016,447)$ overview notes that although it is difficult to quantify the amount of funding going to PPPs for the compulsory phase of schooling, this comprises a relatively small proportion of the overall aid to EFA, where concern with aspects of gender equality, most notably gender parity in enrolment, progression and achievement has been a key feature of donor effort (UNESCO, 2016). She comments the impact of PPPs on policy is more significant than the money invested in them. Thus some of the assumptions they encapsulate about the roles of the public and private sector are more influential than the amounts disbursed through PPP arrangements. Verger (2012) notes the emergence from 2000 of policy entrepreneurs who promoted ideas of PPPs in education, and Ball $(2012 ; 2016)$ has built an ethnography of these transnational networks. Thus, in thinking about PPPs in 
relation to questions of gender equality and women's rights in and through education it is important to take account both of PPPs as a form of education provision in particular contexts marked by gender and other social divisions, and of the ideas associated with PPPs, which may have wider reach than any actual PPP programme. PPPs thus constitute both material relationships, and ideal formations. Aspects of gender are articulated and constituted in both.

The use of PPPs in girls' education and work on gender equality awaits rigorous analysis to consider some effects. We currently have a small literature on PPPs in a few country settings. A number of studies focus on the Punjab in Pakistan, where PPPs have been actively promoted through government and donor programmes to expand education provision. There has been a proliferation of private schools, often actively encouraged by government, although this means there is limited oversight of what is taught and the quality of teachers. The gender effects of these PPPs are disputed. Fennell (2014) found that there appeared to be no preference among parents for selecting private schools, promoted through PPPs for either girls or boys, as parents wanted all their children to get a good education. Amjad and Macleaod (2014) note that students in private schools supported through PPP arrangements have higher learning outcomes than those in public schools, controlling for gender, region and socio-economic status. However, other studies of gender equality and education change in Pakistan question whether PPPs are shifting the forms of gender inequality (Kushid, 2016). It is difficult to generalise from the uneven Pakistan experience with PPPs, gender equality and schooling. The private schooling noted in India and Bangladesh for particular gender effects, do not take the form of PPP, and are more frequently philanthropic, NGO, or commercial organisations. (Asadulah and Chaudary, 2008; Harma, 2009; Woodhead, Frost and James, 2013;Gee, 2015). However, Asadullah and Chaudhury (2009) report on a form of PPP in Bangladesh where rural madrasas undertook some government directed curriculum reform and admitted female secondary school students, while, in return, government paid some teachers' salaries. Their analysis shows regions with this kind of PPP resulting in modernized madrasas were more likely to achieve gender parity in secondary enrolment during 1999-2003, holding the number of secular secondary schools constant. But there is no follow up analysis on gender dynamics in progression, attainment or outcomes beyond school of girls going through these PPP schools and other kinds of secondary school. 
There is limited evidence to investigate whether education PPPs do or do not address marginalisation for girls and the intersection of multiple inequalities, for example of gender, ethnicity and disability more effectively than full public or entirely private provision. A rigorous review of the research into private schools in developing countries (Day et. al., 2014) concluded that the evidence on whether private schools are equally accessed by boys and girls is inconsistent; this study does not comment on what the PPP component of work with private schools adds to the mix. Most of the literature on gender and private schooling, which tends to show some exclusionary effects of private provision, similarly does not single out PPPs from other forms of private schooling (Rose and Subrahmanian 2005; Harma 2016). A review of literature by HEART (2015) found some very limited evidence that PPPs, where the state funds places in private schools, can be beneficial to girls in contexts where there is a good supply of quality private secondary school places.

It can be seen that some studies consider PPPs important for widening opportunities for gender equality in and through education, some see them as deepening inequalities, and a number of reviews are cautious about what can and cannot be claimed for PPPs, gender equality and women's rights. The potential contributions and limitations of PPPs appear highly context dependent. While there are vociferous advocates and critics of PPPs, I have not been able to find any rigorous comparative studies of PPPs and other delivery mechanisms for education associated with expanding girls' schooling opportunities or addressing gender equality. Despite this knowledge gap, a number of donors have assumed that PPPs can overcome some of the problems of inefficiency, lack of accountability and poor programme design and delivery that have been one critique of why many large scale EFA girls' education programmes have not always reached the potential (Draxler, 2015). In the next section, GEC is outlined as an intervention that favoured and used PPPs to deliver expanded provision for girls' schooling.

\section{Girls' Education Challenge}

DFID announced the GEC programme in September 2011, an early initiative of the Coalition government (2010 -2015). $£ 355$ million were announced to assist 1 million 'of the poorest'

girls to 'improve their lives through education' (DFID, 2014). PPPs were a key component of the programme. Publicly funded aid was to be spent in partnership with private organizations. 
"The [GEC] initiative called on non-governmental organizations, charities and the private sector to find better ways of getting girls in school and ensuring they receive a quality of education to transform their future. The GEC is supporting projects that are able to demonstrate new and effective ways to expand education opportunities to marginalised girls" (DFID, 2014).

A number of influences appear to have shaped the perception of the role to be played by PPPs in delivering on girls' education. Firstly, the funding gap in donor support for education, associated with declining aid budgets in the wake of the 2009 financial crisis directed attention to the need to supplement public aid with other sources of finance and skill from the private sector (Bellinger and Fletcher, 2014). Secondly, the intertwining of development assistance with the security agenda became pronounced as the wars in Iraq and Afghanistan unfolded. This brought into sharp relief the question of how to deliver education in conflict affected and fragile states, with some of the largest numbers of girls out of school, but where the conventional notion of a public funding body or stable government was not tenable. (Wild and Elhawary, 2016). Thirdly, considerable achievements in enrolling and supporting girls through school being reported by NGOs, like Camfed, which focused on local, rather than national networking, suggested that much could be achieved by sidestepping the sometimes hostile attitudes within central government and working with local communities, political and religious leaders to build support for girls' schooling (Ansell, 2002; Sutherland- Addy, 2002). All these threads appear germane to the central role accorded PPPs in GEC.

GEC focuses on the non-state sector, a shift from aid strategies under Labour governments, which had advocated Direct Budgetary Support (Hayman, 2011). PPPs involving the NGO sector and private companies are assumed have the capacity to bring girls, currently out of school, quickly into good quality provision and address the problem of girls' marginality. The GEC Business Case argued that DFID's existing education programmes were not responsive enough to reach the most marginalised girls. (DFID, 2012). PPPs and new technologies, are portrayed as innovations, which will address problems of class, race or ethnic social divisions that have contributed to make implementation of public policy in education so difficult. 
GEC has supported 37 projects across 18 countries in Africa and Asia, with funds for projects awarded through a competitive process of bidding for grants. The fund is managed for DFID by a consortium of private consultancy companies led by PriceWaterhouse Coopers.

Features of the programme, such as payment by results for some elements, and implementation of a centrally designed monitoring and evaluation programme intended to enhance efficiency and learning. The aim for Phase 1 entailed 650,000 marginalised girls completing a full six-year cycle of primary school and approximately 1 million marginalised girls completing three years of junior secondary school. Phase 1 will end in June 2017 and a second phase is planned, with $£ 500$ million allocated for a further eight and a half years, extending and expanding interventions from the first phase that accelerate girls' learning outcomes, retention, progression and completion. A catch up programme is planned for girls that have dropped out or never attended school (DFID, 2016).

Phase 1 GEC projects were selected under three funding windows: Step Change aimed to scale up successful interventions, already considered to have positive impact,. Six out of fifteen projects awarded were in conflict areas. Innovation aimed to apply new interventions, technologies, develop new partnerships, or adapt proven solutions for new regions, communities or age groups. Strategic partnerships established matched funding arrangements with the private sector for projects aimed to develop girls' learning. Discovery Communications, The Coca Cola Company, Avanti Communication and Ericsson were the four large corporations involved. (DFID, 2014).

The long term outcomes of the work of GEC and the PPP model deployed cannot yet be assessed. Mid term evaluations tracking the learning gains of the girls in the programme against baseline test results, and a comparison cohort have been completed. The 2016 Annual Review reported uneven results (DFID, 2017). Four outcomes were reviewed improving girls' attendance, improved learning in literacy and numeracy for girls, generating matched funding and developing sustainability to enable girls in the programme to complete a full cycle of education. Intended outcomes for improving attendance and ensuring sustainability were not met in 2016 across all the funding windows. The improved learning target was assessed by the evaluation team as having been exceeded for the programme overall, although projects in the innovation window did not meet this target. Only in the area 
of securing matched funding did all three funding windows meet their targets, generating overall $£ 37.9$ million, the vast majority made up from the private sector companies in the Strategic partnership funding window.

A large centrally managed monitoring and evaluation exercise has assembled baseline and midline information on a cohort of children in treatment groups receiving combinations of the GEC interventions, contrasting their progress with children who have not received the intervention ( Coffey, 2014;Coffey 2016b). This form of evaluation is extremely useful in developing insight into particular intervention combinations that may work to improve girls' literacy, numeracy and attendance, in particular contexts. But it does not directly help us gain insight into whether the PPP form of governance of an intervention might be more or less efficient than one with a different structure and more or less suited to supporting gender equality and women's rights.

The programme evaluator, Coffey (2016b), noted that the one size fits all approach to evaluation had some benefits, but may not fit all contexts. The need to build understanding of GEC at country level, and develop more networks around sustainability was noted in the Annual Review of 2016 (DFID, 2017). The need for this had been raised from a number of sources including an ICAI review of DFID's work on supporting marginalized girls' education (ICAI, 2016) and participants in a panel at the March 2017 Comparative and International Education Society Conference, which reported that GEC projects were evaluated only on girls' learning gains in literacy and numeracy. In some countries the GEC supported projects could not work in schools, and focused on work with communities ${ }^{1}$. However, it was the literacy and numeracy gains in schools, over which the project had little influence, which were evaluated. These disconnections point to areas of learning about PPPs still to be undertaken.

The rigorous 'one size fits all' evaluation of GEC, possibly linked to showing the cost effectiveness in measurable learning outcomes, appears to miss opportunities to learn in depth about work on girls' education, gender and women's rights. Many Step Change projects aim to develop learning materials and support girls' voice. But limited attention is

\footnotetext{
${ }^{1}$ Personal communications by participants in panel CIES conference, Atlanta, 8 March 2017
} 
given to what changes will follow from these forms of expression, and how this might build towards enhancing policy on gender equality or women's rights. None of the Step Change projects appear to focus on building institutions or to address changing the wider institutional context through laws, fiscal regimes or forms of public policy to address equalities. Many stress working with communities, building capacity and governance, but engagement with state institutions is not currently part of the programme remit. Many Step Change projects comment on incentivizing access to school, and establishing safe spaces for learning, but the links between these spaces and wider political economy or socio cultural engagements is not mentioned. Thus girls' access to school is detached from a wider women's rights or gender equality agenda.

In the Innovation Window 20 programmes have been funded, all of which involve adopting new technologies, often linked with communication or green energy. Innovation thus considers different ways of mobilizing finance or forming partnerships around technologies, but the gender dynamics of this is not under review, despite a considerable literature on the ambiguous gender effects of these processes (Kleine, 2013; Webster, 2014; Leach, 2015). In only a handful of projects funded under the Innovation Fund is there any consideration of the changing social perceptions of gender and how to challenge this. Only two projects are concerned with addressing school related gender based violence, often a feature of gender inequalities under conditions of poverty (Parkes, 2015). Thus a minority of the innovations appear to consider undoing deeply entrenched gender inequalities, and the majority appear to work with notions of quick technical solutions presented as innovations.

Part of the rationalisation for the use of PPPs in GEC hinges on the assumption that this form of partnership is particularly well placed to address the problem of girls' marginalisation and exclusion from education. However, according to the evaluations of GEC, PPP project teams have struggled to understand and respond to the complexity of marginalisation. (Coffey, 2015) .Evaluators note that "projects have struggled to understand and address the complexity of educational marginalisation, which could limit the effectiveness of project interventions" and that "not all projects adapted their interventions to address the complex socio-economic factors disadvantaging their target group of marginalised girls"(Coffey, 
2016b). This suggests that PPPs are no better equipped than other forms of project to engage with aspects of context, gender and intersecting inequalities.

Some of the problems with the fragmented approach to addressing gender equality and women's rights evident in the evaluation of the GEC PPPs may lie with a lack of rigour in understanding marginalisation in the initial Girls' Education Challenge Business Case (DFID, 2012). This used a definition of marginalisation taken from a 2010 UNESCO Global Monitoring Report :

Those girls (age: 6 to 19) who have not been enrolled or have dropped out from school (whether living in slums, remote areas, ethnic/religious minorities, girls with disabilities, girls who become pregnant, girls affected by conflict) or are in danger of doing so. (Girls Education Forum, 2016)

There are a number of problems with this way of approaching marginalisation and the policy documents do not explicitly identify PPPs as particularly suited to addressing the problems this definition throws up. Thus the business case definition notes where marginalisation may be evident, but not what comprises it, and how to change it. The classification of marginalisation in listing various characteristics, such as living in remote areas, brings a focus on girls in those areas, who tend to be particularly disadvantaged in educational terms, but it does not show much acuity about how gender is defined or analysed or connected with other forms of social division in these or other areas. This definition resonates with one of the priorities of the 2010-2015 Government Policy: Education in Developing Countries ${ }^{2}$ (UK, 2010), which is "keeping girls - particularly the most marginalised - in school". In other documents, all girls are sometimes described as a marginalised group, as in DFID's Education Strategy $2010-2015^{3}$, which had as an aim to "prioritise girls and other marginalised groups" (DFID, 2010). Thus it is unclear whether marginalisation is the condition of some girls in particular places, belonging to particular groups, or experiencing various difficulties of

\footnotetext{
2 https://www.gov.uk/government/publications/2010-to-2015-government-policyeducation-in-developing-countries/2010-to-2015-government-policy-education-indeveloping-countries

${ }^{3}$ Learning For All: DFID's Education Strategy 2010-2015
} 
embodiment (disability or pregnancy) or whether marginalisation is a condition of all girls, because gender inequality is a cross national social cleavage.

The list based approach about defining marginalisation in GEC, thus has links back to a wider DFID policy framework, and may be part of the reason the organisational form of PPPs, with its fluidity and lack of explicit formulation of ideas about social change may be so useful Three additional problems beset this list based approach to defining marginalisation. Firstly, there is confusion between an effect, that is girls out of school, and the cause. In the GEC business case marginalisation is linked with place (slums, remote areas) and the implication is that PPP interventions need to be directed to particular places. But focussing only on the girls who live in these places, rather than explicitly addressing the structures, policies, lack of resources, multidimensional conditions that create those places as a site of exclusion with particular gender dynamics, does not help address sustainable change. For example, it is not living in slums that is the problem, although clearly these areas are associated with poor housing, lack of health and infrastructure. Underlying these effects are ways that slums are under resourced, located in social development peripheries, and poorly governed generating particular gender dynamics (Chant and Mcllwaine, 2015). A similar blurring is linked with ethnicity. It is not a problem that girls are of a particular ethnicity, but that discriminations are enacted on particular ethnic groups, connecting gender and other inequalities. Thus interventions only at the level of the girls, without a more worked out Theory of Change to address the deeper problems of why inequalities between and within ethnic groups persist and take particular gender forms, are less likely to bring about sustainable change that makes a profound difference. Although PPPs might be efficient in delivering some interventions, they may be less effective than other delivery mechanisms in addressing sustainable change, but as yet there is no evidence either way on this.

A second problematic feature with the approach to defining marginalisation is a disregard for a refined analysis of the gender dynamics of a particular problem. With regard to girls who are marginalized because of conflict, the nature of conflicts generally means that whole populations, regardless of their status or assets are affected (Nicolai et al., 2015), although a number of studies show how wealth or level of education can ameliorate some of the hardships associated with conflict (Winthrop and Matsui, 2013). However, the literature on gender, education and conflict (Mundy and Dryden-Peterson, 2011) indicates that 
marginalisation in this context frequently refers to inadequate concern with gender in the general humanitarian and post conflict approach to education. Evidence is still needed on how girls experience particular kinds of marginalisations in conflict and how PPPs or other delivery mechanisms can help address this.

A third problematic feature of the view of marginalisation is its failure to fully engage with women's rights issues. The DFID GEC business case links pregnancy and marginalisation, but does not unpack this further. A discussion paper by UNESCO (2015) on the education response to early, unintended pregnancy highlighted that the concerning issue is not pregnancy, but pregnancies that are early, unintended or associated with stigma and discrimination. Much more investigation is needed into women's reproductive rights and how to connect activists, practitioners and policy makers who work in this area. Whether PPPs support or undermine rights based activity needs documentation.

Thus marginalisation needs more sustained analytic work disentangling whether addressing marginalisation is about working with some effects - for example girls out of school - , or whether engaging with marginalisation entails work on deeper causes, which require not simply a list of 'factors' but an assessment of the historical, structural gender dynamics entailed and the ways these play out in particular relationships and practices. This raises centrally the question of under what conditions and to address what kinds of problems PPPs might be an appropriate response.

GEC involves a range of actors from different kinds of transnational organization (INGOs, multinational corporations) engaged in project implementation, management, promotion, and evaluation. However, groups that are strikingly absent from the GEC engagement are global feminist organisations, trade unions and transnational organisations of rural marginalized groups such as la Via Campesina. UNESCO and UNICEF signed the Girls' Eduction Forum (2016) statement on addressing marginalization, launched at an event to promote GEC, but are not directly involved in the programme. The GEC dataset is a considerable research resource, but a scholarly programme to investigate this data has not yet been developed.Despite the considerable research input into GEC, it has not yet yielded a form of PPP engagement with communities of practice in universities or other circles which connect 
research, policy and practice to deepen reflection on gender equality, women's rights and girls' schooling.

GEC as an example of a PPP thus has many facets, but it is not yet possible to document the outcomes of this form of intervention on gender equality or long-term enhanced access to education for girls experiencing poverty and inequality. GEC has used the PPP mechanism because of evident of failures of state provision of education for the poorest with some clear gender dynamics. But using the PPP model still begs the question of how to address the institutional, economic or political basis of gender and connected inequalities. GEC has promoted very little dialogue with critical communities of women's rights activists or gender and education scholars. The PPP form of governance for programmes in girls' education appears efficient because it views girls' education as a form of malaria net, to be efficiently delivered, leveraging private finance and the skills and commitments of NGO organisers. But in studying PPPs and gender equality in education what we need to understand is not only a limited number of outputs, which the GEC RCT will provide information on, but the complexities of contexts and the sustainability or fragility of outcomes. It is these questions the PPP form deployed by DFID in the GEC fails to flick on.

In the next section I consider how to make sense of PPP programmes which, like GEC. Lean in two directions. On the one hand, these tend towards supporting the expansion of rights to education. On the other these engage only minimally with building gender equalities through education, or supporting changing institutional conditions to advance substantive gender equality, to connect with a wider agenda of women's rights. In trying to understand this ambiguous process I attempt to set out some lines of enquiry for future work on how to understand these experiences.

\section{Framing PPPs in girls' schooling: Multipolarity and dispersal}

It is possible to chart the heistory of global and national concerns with gender equality and girls' schooling as moving through phases framed by women's rights articulated bottom up and top down, through concerns with empowerment and changing unjust structures of gender inequitable power, moving towards struggles over whether to include or ignore 
substantive gender equality and get girls into school, achieving a minimal set of learning outcomes (Unterhalter, 2016). As part of this history I consider GEC and the PPPs, which are central to its delivery, as representing a move away from the integrated connections of rights and equalities, articulated in the Beijing Platform of Action, and struggled over from 1995 to the present. I see GEC as exemplifying the emergence of a new framework for understanding work on gender and education. Because of its contrast with the integrating moves of the previous era I have termed this new framework dispersal.

In two recent articles which try to specify features of the framework of dispersal I have made some analysis (Unterhalter, 2015; Unterhalter, 2016) of the diverse ways in which ideas about gender equality and education are being invoked, simultaneously linked with, on the one hand, notions of public good and social transformation, and, on the other, with private profit in a number of different guises. I have used the notion of multipolarity as a heuristic, to try to grasp some of the ways in which contrasting dynamics are held together. I have called the process I am trying to document dispersal, because it intermixes relations between the global, the national and the local, the public good and the private, which can take a form of corporate social responsibility, or a form of corporate action that is deregulated, and actively or inadvertently promotes inequalities. Dispersal undermines some old assumptions of left/right division, and makes for a disoriented politics. For example, social democratic states, generally a project of the left, may actively promote PPPs, and waive regulation of the private companies they partner with; they thus adopt strategies of small state, more often a project of the right. Similarly, parties of the right may articulate strategies of the left, such as David Cameron's notion of the 'big society'. Thus the notion of dispersal evokes features of contemporary relationships where different spaces of governance, policy or distribution undercut each other in ways that parody or undermine key processes or practices that might try to effect the conditions for integrating work on equalities and rights.

PPPs appear as key instances of dispersal, and the ideas which are used to argue for their effectiveness show how this framework operates both in shaping relationships of policy, practice and research. I associate dispersal as a framing with a number of features. Firstly, a particularly fluid meaning assigned to gender. Secondly, oscillations between a pragmatic politics of power, and a heterodox engagement with divergent politics of voice, which I have 
termed multipolarity. Thirdly, a form of education that is confusingly both part of the problem and part of the solution to widening global inequalities. GEC and the forms of PPPs involved provide examples of all these features of dispersal as a framework to understand contemporary formations of engagement with gender and girls' schooling.

The GEC projects deploy diverse understandings of gender. Some focus simply on getting girls into school, a framework I have described as viewing gender as a noun, drawing on ideas about Women in Development (Unterhalter, 2005; Unterhalter, 2012). Others show some concern to work with communities to examine ideas about gender. In my own discussions with GEC partners at meetings, conferences and on field visits I have heard a wide range of understandings expressed encompassing some seeing this work as advocating for equalities, while for others it entails ensuring girls are kept clean or away from teenage sex. GEC projects may be understood to work with what I have termed approaches that view gender as an adjective, colouring relationships of power and access to resource (Unterhalter, 2005, 2012; 2016). But as a programme GEC does not distil a clear vision of gender equality in education and the aim of each constituent project is to interpret marginalisation and gender equality differently. Thus GEC exemplifies the approach I have called defining gender as a gerund (Unterhalter, 2016) where the orientation to equalities or women's rights is sometimes present and sometimes absent. The equalities dynamic of the project blinks on and off, and this uncertain meaning of gender equality is one feature of the framework of dispersal, where some commentators on transnational feminism note how policy has moved away from the integrated focus of the Beijing Platform to more superficial engagements with aspects of women's employment, or girls' education (Baksh and Harcourt, 2015).

A second facet of dispersal as a framework is a double entendre about politics, which provides a perspective on why it is difficult to make a definitive judgement about PPPs. Multipolarity appears useful as a metaphor for thinking about this. Multipolarity is a double sided word. Thus it helps to try to understand some of the confusion and complexity of PPPs, which appear to offer much as a win-win harnessing of the best of both public and private, but confusingly do not always deliver, as some of the evaluations of GEC illuminate (Coffey 2015; Coffey, 2016b; DFID, 2017). 
Within international relations the notion of multipolarity is sometimes used as a shorthand to indicate the changes in power away from a unipolar world directed by US co-ordination, leadership,or dominance (depending on viewpoint) (Layne, 2011). Multipolarity as a term is used to characterise features of the present governance agenda where it is not clear whether geopolitics is directed by processes of balance, tipping points, hard or soft power, and the delimitations between public and private institutions are sometimes merged. (Baylis, Smith and Owens, 2013; Haggard, 2014). Multipolarity is also used by governments in emerging economically influential states, such as the BRICS to express a notion of equal sovereignty, or an alternative to visions of global governance articulated by the US or the EU (Jaeger, 2014). Institutions like the BRICS bank underpin the concept, as do gatherings like the $\mathrm{G} 20$ each of which suggests different governance notions and connections of accountability. Some of the international relations dilemmas of the last years about how to engage with Russia, China and Iran all express some of the complexities of living in a multipolar world. In this perspective multipolarity is about realism, negotiating with the geo-political powers that govern territory, control economies, and can direct wars. This can entail that acknowledging these realities and their contradictions, one can still hope to edge forward values around rights, equalities, sustainability, social solidarities or minimising conflict . But it is also possible to bracket these normative concerns, or pick them up selectively linked with other desired processes, for example free trade, or the efficiency of PPPs . The stress on process, leaves open the normative questions. These include, for example, why does accountability in education matter, particularly in relation to gender and connected equalities? Who is accountable to whom and for what? How are public and private forms of accountability different, and what new hybrids of the notion are needed for PPPs? In the first meaning of multipolarity these niceties of social justice questions are less important than getting things done, for example through PPPs, acknowledging the complexities of power.

There is, however, a second meaning of the word multipolarity formulated from a perspective concerned with theorising radical democracy. Chantal Mouffe (2008) has argued for a multipolar world order that recognises multiple understandings of identities, democracy and human rights, and where politics, not governance is the key term. For Mouffe this plurality is a refusal of the dialectic, which establishes boundaries, exclusions 
and antagonisms associated with domains of political power and, by implication, a separation of the public and the private. Mouffe's idea of agonism entails 'how to establish this us/them distinction, which is constitutive of politics, in a way that is compatible with pluralism' (Mouffe, 2013, 6-7). A key thread in the version of multipolarity advanced by Mouffe is the acknowledgement of agonistic relationships, in which gender, like race may play a central role, but not imply us/them, insider/outsider distinctions. By their complexity, differential salience, and possible difference for different groups, attachment is built to a democratic project that is pluralist, engaged in discussion, fluidity and multiplicities. A key thread is her acknowledgement of a version of multipolarity, in which there are multiple different vernacular ideas about democracy and engagements with politics that might or might not be secular, linked with particular institutions or ideas about rights, and by implication articulate different philosophies of education or governance, and open a terrain for examination of different kinds of inequalities. Multipolarity from this perspective is about a social justice project that is shifting, enacted, contested, responsive to the complexities of location and mobility. Normative frames are not pre-given, canonical but always negotiated, accepting agonistic processes. A singular meaning of governance is not in her vocabulary, and a 'reading off' particular resonances of public or private, as good or bad is refused in this analysis. PPPs would always be negotiated in a politics of the here and now, reflecting on histories and aspirations.

These two meanings of multipolarity are useful in trying to understand contestations over some key words in the lexicon of gender and development, such as empowerment, equity, and efficiency (Cornwall and Eade, 2010; Harcourt, 2016; Unterhalter, 2017). I see these terms as areas of struggle, where particular intellectual and political moves need to be made to link these words to an arc of justice, rather than as a superficial veneer on governance agendas, which ignore or fail adequately to engage with continued relationships of violence, dispossession and exploitation. Understanding how PPPs are realised in policy and practice allows us to see how these words are deployed, and the multipolar ways in which dispersal operates as a form a discourse and a set of relationships that stitch together sometimes surprising partnerships.

Multipolarity is the heuristic, which seems to show how in the contemporary period of work on gender, schooling and international development, the signal about gender equality and 
women's rights blinks on and off. It oscillates between two positions. One resonates with the first meaning of multipolarity, where the politics are pragmatic, linked with maintaining or not challenging the existing geopolitical order and the associated governance regimes . This invokes gender and education as a form of soft power linked with aid, status or military strategy, as is evident in some feature of the work of GEC. There are comparative examples of this kind of initiative, and its formation through PPPs. In the UK today there is a confusing situation, where the government enacts harsh anti-austerity programmes at home, cutting funding for local organisations working on anti-trafficking or women's refuges (Ishkanian, 2014). It has not adopted the Istanbul Convention on Violence against Women and Domestic Violence. Yet internationally, DFID, and a number of PPP initiatives position the UK as a major spokesperson on challenging violence against women. A high-level event on this in 2015 attended by celebrities and key political figures drew in both governments and the private sector, activists, and academics (Kirby, 2015). In both GEC and the work on violence against women (VAW) the fluidity of the notions in play do not destabilise existing power blocs. They thus can be understood as formations of the 'realist' form of multipolarity. We can thus describe GEC as multipolar, but not multilateral or feminist activist.

But a second Mouffean meaning of multipolarity is also evident in these programmes. A number of case studies of work at grassroots level for GEC, or for forms of PPP around girls' schooling document the existence of networks of radical organisations associated with educational practices that engage locally, nationally and globally around claiming a space for gender and challenging existing thinking which limits meanings of gender, equality and education (Perezenieto, 2016; Parkes, et al, 2016). This heterodox process, sometimes led by activist networks, exists sometimes outside government, NGOs or multilateral bodies, sometimes loosely allied with particular blocs within it, sometimes using and reshaping PPPs, but sometimes constrained by them and engaged in critique. However, critical voices are muted, diffident, and aware of the power associated with funding and status.

Multpolarity as a metaphor enables me to distil how in contemporary times we see PPPs linked to global frameworks concerned with gender and education, both a social justice process concerned with equalities, difference and solidarity and as a minimalist instrumentalist process that at best ignores, and at worst undermines social justice 
dynamics. The notion of multipolarity enables me to distil how these processes are working at the same time.

A third feature of the dispersal framework is the way that education operates both as an opportunity for some and a barrier for others. Across the world the promises of educational and economic growth or enhanced social solidarity have been achieved only for some. In some parts of the world trends in access to school are going downward because of terrible war, forced migrations or lack of provision. We place a great deal of hope in education, but, as annual volumes of the UNESCO Global Education Monitor shows, we have not realised these aspirations for all people on the planet (UNESCO, 2016). The financial crisis of 2008 has exacerbated these trends, diminishing the financial resources available for education expansion, but leading elites to invest more heavily in the positional forms of education that secure their advantage. We thus see higher education expanding access including for many women, but reducing quality for many groups, primarily affecting fractions of the middle class (Schendel and McCowan, 2016), at the same time elite multiversities, concentrate intellectual, social and financial capitals (Marginson, 2016). The process with a simultaneous concentration of capital for some and a widening of inequalities for others recalls Piketty's (2014) delineation of contemporary capital. These trends have been exacerbated since the 2008 financial crisis, and have particular gender effect. Thus, for example, the expansion of education opportunities for women, and their entry into the labour market, may be part of the story of wages being kept down. It may also be part of the tragic choices migrant domestic workers have to make. They are torn between taking care of their own children in person or sending money home, saved from employment giving commodified care to other people's children. This work enables their employers to access high paid jobs with long hours or further study or travel. The notion of dispersal tries to capture the idea that education may be both part of the problem of widening inequalities, but is a key resource for trying to address and challenge these.

Are PPPs concerned with gender and girls' school part of the problem of dispersal, or an attempt to build towards a more solid form of social democracy rooted in ideas about equality and women's rights? To understand how dispersal works as a framework which organises contemporary initiatives on gender and education, we need an evaluative 
perspective and grounded contextual critique to detail how ideas and relationships, concerned with PPPs or other iconic features of contemporary social policy, work in particular settings. In each country the nature of the education challenges around delivery, accountability, participation, sustainability and equalities are different, saturated with history, and driven by the difficulties of the contemporary moment. PPPs appear too shallow and uniform a solution to the diversity of these problems, and the projects funded for GEC exemplify this. But to understand the process better we need to know in detail how PPPs work on the ground and what they illuminate about frameworks for analysing gender and education. We need some engagement with what might distinguish a social justice and feminist response to dispersal and the GEC PPPs. We need insight into how these connect with local, national and transnational struggles, critical epistemologies, and ways to understand the connections of inequalities and strategies to realise equalities in and through schooling

\section{Conclusion}

The article has looked at a range of ways in which PPPs in education have been defined, outlined DFID's GEC, as one example of a PPP, and discussed dispersal, as a framework for thinking about PPPs, gender and education that captures some of the plasticity being attributed to the notion of gender, the diverse politics signalled by the double entendres of multipolarity, and some of the difficulties and possibilities cohering around education.

The discussion of dispersal and multipolarity identifies certain features of the framework which seem to explain the oscillations around gender signalled by PPPs. These entail a plurality of ideological, organisational and material engagements with addressing marginalisation, girls' schooling, and gender equality. Often the substantive issues, that talk to concerns of women's rights and the realm of public social policy reform are overlooked for addressing an immediate need to get girls into school. This resonates with approaches to addressing health needs or poverty that have gone for the most immediate intervention, for example the inoculation, the malaria net, or the cash transfer, rather than the detailed understanding connected forms of inequalities and dispossession and developing integrated programmes to address these. We cannot read off from the organisational form of PPPs whether they are in themselves good or bad for gender equality, girls' schooling or 
advancing a women's rights agenda. These assessments have to be made in context, taking adequate account of the views of those affected by the interventions. A feature of dispersal as a framework, and multipolarity as a contested politics associated with it, is the way policy advocacy tends to float away from the detail of what is actually happening to whom where, and for what reasons. Understanding how to work better for gender equality in education always needs to be connected to the detail of context, and the complexities of building solidarities across differences. PPPs may, under some circumstances, offer one small part of this project, but much more investigation is needed for us to understand how or whether they build toward its heart. We need much more investigation to know whether they offer a compelling way to realise gender equality and women's rights or a diversion from this project. 


\section{References.}

Andrabi, T., Das, J. and Khwaja, A.I. (2002). The Rise of Private Schooling in Pakistan: Catering to the Urban Elite or Educating the Rural Poor. Washington, DC: World Bank

Ansell, N. (2002). Secondary education reform in Lesotho and Zimbabwe and the needs of rural girls: Pronouncements, policy and practice. Comparative Education, 38(1), 91-112.

Amjad, R., \& MacLeod, G. (2014). Academic effectiveness of private, public and privatepublic partnership schools in Pakistan. International Journal of Educational Development, 37, 22-31.

Asadullah, M. N. (2008). Madrasas and NGOs: complements or substitutes? non-state providers and growth in female education in Bangladesh Washington:. World Bank Publications.

Asadullah, M. N., \& Chaudhury, N. (2009). Holy alliances: public subsidies, Islamic high schools, and female schooling in Bangladesh. Education Economics, 17(3), 377-394.

Baksh, R., \& Harcourt, W. (Eds.). (2015). The Oxford handbook of transnational feminist movements. Oxford University Press, USA.

Ball, S. J. (2012). Global education inc: New policy networks and the neo-liberal imaginary. Abingdon: Routledge.

Ball, S. J. (2016). Following policy: networks, network ethnography and education policy mobilities. Journal of Education Policy, 1-18.

Baylis, J., Smith, S., \& Owens, P. (Eds.). (2013). The globalization of world politics: an introduction to international relations. Oxford: Oxford University Press.

Bellinger, A., \& Fletcher, B. (2014). Non-Traditional Financing for Education London: DFID.

Brans, B., 2013, 'Public Private Partnerships in Uganda: More perils than promises for Universal Secondary Education in Verger, T., Altinyeken, H., and De Koning, M. eds. Global managerial education reforms and teachers Brussles: Education International Research Institute, 74-90

Chant, S., \& Mcllwaine, C. (2015). Cities, slums and gender in the global south: towards a feminised urban future. Routledge.

Chant, S. (2016). Women, girls and world poverty: empowerment, equality or'essentialism?. International Development Planning Review, 38(1), 1-24.

Coffey (2015) Baseline Report - Step Change Window. Girls' Education Challenge Fund. https://www.gov.uk/government/uploads/system/uploads/attachment data/file/425360/S tep-change-window-full2.pdf 
Coffey (2016a) Narrow Windows, Revolving Doors GEC Thematic Research Report, Evaluation Manager Girls' Education Challenge Fund UK Department for International Development

Coffey (2016b) GEC Process Review Report Evaluation Manager Girls' Education Challenge Fund London: Coffey on line at http://www.coffey.com/en/ingenuity-coffey/girlseducation-challenge-fund-process-review-what-has-worked-what-has-not-and-why-abriefing-for-decision-makers/

Cornwall, A., \& Eade, D. (2010). Deconstructing development discourse: Buzzwords and fuzzwords. Oxford: Practical Action

Day, A., Mcloughlin, C., Aslam, M., Engel, J., Wales, J., Rawal, S., Batley, R., Kingdon, G., Nicolai, S. and Rose, P. (2014). The role and impact of private schools in developing countries: a rigorous review of the evidence. Final report. Education Rigorous Literature Review. Department for International Development.

https://www.gov.uk/government/uploads/system/uploads/attachment data/file/439702/p rivate-schools-full-report.pdf

DFID, 2010, Learning For All: DFID's Education Strategy 2010-2015 London: DFID

DFID (2012) Girls Education Challenge Business Case http://devtracker.dfid.gov.uk/projects/GB-1-202372/documents/

DFID (2014) Girls' Education Challenge Investing in Business innovation and partnerships for girls' education https://www.gov.uk/government/uploads/system/uploads/attachment_data/file/192643/a bout-strategic-partnerships.pdf

DFID (2015) Girls' Education Challenge: Project Profiles [online] Available at https://www.gov.uk/government/uploads/system/uploads/attachment data/file/415489/G EC-Project-Profile-booklet-March2015.pd

DFID (2016), Press release on GEC, London: DFID on line at https://www.gov.uk/government/news/britain-to-help-175000-girls-in-worlds-poorestcountries-get-an-education 
Draxler, A., 2015 'Public Private Partnerships in Education ‘ in McGrath, S., \& Gu, Q. (Eds.).. Routledge Handbook of International Education and Development. Routledge.

Duflo, E. (2012). Women empowerment and economic development. Journal of Economic Literature, 50(4), 1051-1079.

Fennell, S. (2014). Public-Private Partnerships in Education and the Pursuit of Gender Equality: A View from South Asia, International Development Policy, 5(3).

Fisher, J. (2015). 'Does it Work?'-Work for Whom? Britain and Political Conditionality since the Cold War. World Development, 75, 13-25.

Girls Education Forum, 2016, Statement of action to accelerate marginalized girls' education outcomesLondon: Girls Education Forum

Gee, K. A. (2015). Achieving gender equality in learning outcomes: Evidence from a nonformal education program in Bangladesh. International Journal of Educational Development, 40, 207-216.

Harcourt, W. (Ed.). (2016). The Palgrave Handbook of Gender and Development: Critical Engagements in Feminist Theory and Practice. Dordrecht: Springer.

Härmä, J. (2009). Can choice promote Education for All? Evidence from growth in private primary schooling in India. Compare, 39(2), 151-165.

Harma, J., 2015, 'Private schooling and development: An overview' in P. Dixon, S. Humble and C. Counihan, eds. Handbook of International Development and EducationCheltenham: Edward Elgar, 171-199.

Hayman, R. (2011). Budget Support and Democracy: a twist in the conditionality tale. Third World Quarterly, 32(4), 673-688.

Ishkanian, A. (2014). Neoliberalism and violence: The Big Society and the changing politics of domestic violence in England. Critical Social Policy 34.3: 333-353.

Haggard, S. (2014). Liberal pessimism: international relations theory and the emerging powers. Asia \& the Pacific Policy Studies, 1(1), 1-17. 
Health and Education Advice and Resource Team (2015) Helpdesk query: Evidence on girls' secondary education. http://www.heart-resources.org/wpcontent/uploads/2016/01/HEART-Helpdesk-girls-secondary-education.pdf

Jaeger, H. M. (2014). 'Neither Cosmopolitanism nor Multipolarity: The Political Beyond Global Governmentality. In E. Swynegedou The Post-Political and Its Discontents Oxford: Oxford University Press 208-228.

Kristof, N. D., \& WuDunn, S. (2010). Half the sky: Turning oppression into opportunity for women worldwide. New York: Vintage

Kelly, O., Krishna, A., \& Bhabha, J. (2016). Private schooling and gender justice: An empirical snapshot from Rajasthan, India's largest state. International Journal of Educational Development, 46, 175-187.

Khurshid, A. (2016). Domesticated gender (in) equality: Women's education \& gender relations among rural communities in Pakistan. International Journal of Educational Development, 51, 43-50.

Kirby, P. (2015). Ending sexual violence in conflict: the Preventing Sexual Violence Initiative and its critics. International Affairs, 91(3), 457-472.

Kleine, D. (2013). Technologies of choice?: ICTs, development, and the capabilities approach. Boston: MIT Press.

LaRocque, N. (2008). Public-private partnerships in basic education: An international review. CfBT Education Trust.

Layne, C. (2011). The unipolar exit: beyond the Pax Americana. Cambridge Review of International Affairs, 24(2), 149-164.

Manjrekar, N. (2013). Women School Teachers in New Times: Some Preliminary Reflections. Indian Journal of Gender Studies, 20(2), 335-356.

Marginson, S. (2016). The Dream Is Over. Berkley: University of California Press. 
Menashy, F. (2014), Private Sector Engagement in Education Worldwide: Conceptual and Critical Challenges, in Alexander W. Wiseman , Emily Anderson (ed.) Annual Review of Comparative and International Education Bingley: Emerald pp.137-165

Menashy, F. (2016). Private Authority or Ambiguity? in A. Verger, C. Lubienski and G. Steiner-Khamsi eds. . : The Global Education Industry, Abingdon: Routlede, 63-.

Mouffe, C. (2005). On the political. London: Routledge

Mouffe, C., 2013, Agonistics London: Verso

Mundy, K. Dryden-Peterson. S. (2011). Educating Children in Conflict Zones: Research, Policy, and Practice for Systemic Change--A Tribute to Jackie Kirk. New York: Teachers College Press.

Nicolai, S., Hine, S., Wales, J. (2015). Education in emergencies and protracted crises: Toward a strengthened response. London: Overseas Development Institute

Parkes, J. (Ed.). (2015). Gender violence in poverty contexts: the educational challenge. Routledg

Parkes, J., Heslop, J., Januario, F., Oando, S., \& Sabaa, S. (2016). Between tradition and modernity: girls' talk about sexual relationships and violence in Kenya, Ghana and Mozambique. Comparative Education, 52(2), 157-176.

Patrinos, H. A., Osorio, F. B., \& Guáqueta, J. (2009). The role and impact of public-private partnerships in education. World Bank Publications.

Pestoff, V., Brandsen, T., \& Verschuere, B. (Eds.). (2013). New public governance, the third sector, and co-production Abingdon: . Routledge

Perezenieto, P. (2016). UNGEI Good Practice Fund: Synthesis Report. ODI, available online at https://www.goodpracticefund.org/documents/Synthesis-Report-v3.pdf

Piketty, T. (2014). Capital in the 21st Century. Cambridge: Harvard University Press 
Robertson, S., Mundy, K., \& Verger, A. (Eds.). (2012). Public private partnerships in education: New actors and modes of governance in a globalizing world. Edward Elgar Publishing.

Rose, P. (2010) Achieving Education for All through public-private partnerships?, Development in Practice, 20:4-5, 473-483,

Rose, P.ed. (2013). Achieving Education for All through Public-Private Partnerships?: NonState Provision of Education in Developing Countries.Abingdon: Routledge.

Rose, P. and Subrahmanian, R. (2005) Evaluation of DFID Development Assistance: Gender Equality and Women's Empowerment - Phase II Thematic Evaluation: Education http://www.ungei.org/resources/files/dfid wp11.pdf

Schendel, R., \& McCowan, T. (2016). Expanding higher education systems in low-and middleincome countries: the challenges of equity and quality. Higher Education, 72(4), 407-411.

Smith, W. C., \& Joshi, D. K. (2016). Public vs. private schooling as a route to universal basic education: A comparison of China and India. International Journal of Educational Development, 46, 153-165.

Srivastava, P. (2010). Public-private partnerships or privatisation? Questioning the state's role in education in India. Development in Practice, 20(4-5), 540-553.

Sutherland-Addy, E. (2002). Impact assessment study of the girls' education programme in Ghana. Accra: UNICEF.

.Switzer, H. (2013). (Post) Feminist development fables: The Girl Effect and the production of sexual subjects. Feminist Theory, 14(3), 345-360.

UK, 2010 Government Policy in developing countries London: , https://www.gov.uk/government/publications/2010-to-2015-government-policy-educationin-developing-countries/2010-to-2015-government-policy-education-in-developingcountries

UNESCO 2015, Early unintended pregnancy. What role for education? (Paris: UNESCO on line at http://www.unesco.org/new/en/education/themes/leading-the-international- 
agenda/health-education/single-

view/news/early and unintended pregnancy what role for education/

UNESCO (2016) Education for people and planet: creating sustainable futures for all. Global Education Monitoring Report 2016, Paris: UNESCO,

Unterhalter, E. (2005). Fragmented frameworks? Researching women, gender, education and development. In S.Aikman and E. Unterhalter ed. Beyond access: Transforming policy and practice for gender equality in education, Oxford: Oxfam 15-35.

Unterhalter, E. (2012). Mutable meanings: gender equality in education and international rights frameworks. Equal Rights Review, 8, 67-84.

Unterhalter, E., 2007, Gender, schooling and global social justice Abingdon: Routledge

Unterhalter, E. S. (2015). Global inequalities, multipolarity, and supranational organizations engagements with gender and education. Journal of Supranational Policies of Education, 3, 10-28.

Unterhalter, E., 2016, 'Gender and education in the global polity' in Mundy, K., Green, A., Lingaard, B. and Verger, A. eds. Handbook of global education policy New York: Wiley, pp. 111-127.

Unterhalter, E., 2017 forthcoming, 'Balancing pessimism of the intellect and optimism of the will: Some reflections on the capability approach, gender, empowerment, and education' in D.Clark, A. Frediani and M. Biggeri eds.- The Capability Approach, Empowerment and Participation: Concepts, Methods and Applications London: Palgrave

Verger, A. (2012). Framing and selling global education policy: the promotion of publicprivate partnerships for education in low-income contexts. Journal of Education Policy, 27(1), 109-130.

Warner, A., Malhotra, A., \& McGonagle, A. (2012). Girls education empowerment and transitions to adulthood: The case for a shared agenda. Washington: D.C., International Center for Research on Women 
Webster, J. (2014). Shaping women's work: Gender, employment and information technology. Routledge.

Wild, L., \& Elhawary, S. (2016). The UK's approach to linking development and security: assessing policy and practice. In S. Brown and J. Gravingholt. ed The Securitization of Foreign Aid London: Palgrave Macmillan , . 42-63..

Winthrop, R., \& Matsui, E. (2013). A new agenda for education in fragile states. Center for Universal Education at Brookings.

Woodhead, M., Frost, M., \& James, Z. (2013). Does growth in private schooling contribute to Education for All? Evidence from a longitudinal, two cohort study in Andhra Pradesh, India. International Journal of Educational Development, 33(1), 65-73. 